\title{
Da contestação à conversão: a punição exemplar dos réus da Conjuração Baiana de 1798
}

Patrícia Valim

Na manhã de 12 de agosto de 1798, boletins manuscritos foram afixados em locais públicos da cidade de Salvador, convocando a população para uma "revolução" que implantaria a "República Bahinense". Para a implantação do novo regime de governo, no boletim intitulado "Aviso", a população foi informada que 676 pessoas eram partidárias do movimento que objetivava acabar com o jugo da dominação portuguesa e a abusiva cobrança de impostos no Brasil, entre outras medidas que assegurariam o incentivo para o comércio de pau-brasil, tabaco, açúcar e para os demais gêneros de negócio. Em um outro boletim, a mensagem para a população era muito clara: "Animai-vos povo bahinense que está para chegar o tempo feliz da nossa liberdade; o tempo em que todos seremos irmãos; o tempo em que todos seremos iguais..."

No mesmo dia, d. Fernando José de Portugal e Castro, governador da Bahia, ordenou que se abrisse uma investigação para se descobrir o(s) autor(es) de tão "odiosa empresa". Assim que d. Fernando ordenou a instauração da devassa seguiu-se a prisão de Domingos da Silva Lisboa, após um precário exame das letras dos boletins e algumas petições da Secretaria de Estado e Governo do Brasil, sob o comando de José Pires de Carvalho e Albuquerque. ${ }^{2}$ Todavia, no dia 20 de agosto de 1798, foram encontradas duas cartas na Igreja do Carmo assinadas pelos anônimos republicanos. ${ }^{3}$ A primeira delas foi destinada ao prior dos carmelitas descalços e afirmava

Reverendíssimo em Christo Padre Prior dos Carmelitas Descalços: e para o futuro Geral em Chefe da Igreja Bahinense: segundo a secção do Plebiscito de 19 do corrente: quer e manda o Povo que seja feita a sua revolução nesta Cidade por conseqüência de ser exaltada a bandeira da igualdade, Liberdade, e fraternidade Popular, portanto manda que todo o sacerdote Regular e Irregular assim o aprove, e o en[ten]da alias... ..Vive et vale. ${ }^{4}$

A segunda carta foi para o governador, d. Fernando José de Portugal e Castro:

Illustrissimo e Excellentissimo Senhor, o Povo Bahinense, e Republicano na secção de 19 do prezente mez houve por bem eleger; e com efeito ordenar que seja Vossa Excellencia invocado compativelmente como cidadão Prezidente do Supremo [Tribu]nal da Democracia B[ahinense] para as funcoens, da futura revolução, que segundo o Plebiscito se dará no prezente pelas duas horas da manhã, conforme o prescripto do Povo. Espera o Povo que Vossa Excellencia haja por bem o exposto. Vive et vale. ${ }^{5}$

O desembargador Avellar e Barbedo não verificou as informações sobre o governador ter sido escolhido o chefe do que viria a ser a "República Bahinense". Tampouco procurou investigar a relação do prior dos carmelitas descalços com os partícipes da revolta. No entanto, como os carmelitas descalços foram convocados pelas autoridades locais a tomarem confissão e acompanharem os condenados em seus últimos dias de vida, no Segredo da Relação, é possível sabermos como foram esses momentos, graças a dois relatos do prior do Convento de Santa Tereza, Frei José do Monte Carmelo.

O primeiro relato se encontra no Arquivo Histórico Ultramarino sob o título "Notícia da execução que se fez na Bahia em 8 de novembro de 1799 aos libertinos que saíram produzidos na sentença da Relação da sublevação intentada na cidade da Bahia". O segundo está guardado no Arquivo do Instituto Histórico e Geográfico Brasileiro sob o título “Outra relação feita pelo P. Fr. Joze D’Monte Carmelo, religiozo carmelita descalço". ${ }^{6}$ Ainda que os relatos tenham conteúdos distintos, suas relevâncias vão além de relatar o suplício daqueles quatro homens, uma vez que os relatos suscitam duas questóes importantes acerca do conhecimento que se tem atualmente da Conjuração Baiana de 1798. 
Trata-se da posição de um religioso cristão em relação às forças diametralmente opostas no final do século XVIII: razão/revelação; liberdade/despotismo; natureza/civilização; moral/política; luzes/trevas. Depois, ao resgatar o drama do enforcamento em praça pública dos quatro condenados, o carmelita descalço deixa em aberto em sua narrativa que não foram eles os únicos culpados no "delito de sublevação", sugerindo ter havido iniquidade do poder local em relação à circunscrição social do evento. É o que se apresenta neste artigo.

Conta-nos frei José do Monte Carmelo, carmelita descalço ${ }^{7}$ e prior do Convento e Igreja de Santa Teresa, que Manuel Faustino, depois de ser preso no segredo da Relação, tentou se suicidar várias vezes por influência nefasta do demônio. Como o réu foi livrado da morte em todas as vezes, ele voltou-se à mãe de Deus porque a "malícia ainda não tinha lançado raizes fundas no seu coração", passando seus últimos dias de vida rezando de dia e de noite. ${ }^{8}$ Mas, no dia 5 de novembro de 1799, após “todos os delinqüentes"9 terem sido chamados para ouvirem as sentenças que os condenariam à morte, Manuel Faustino e os outros condenados voltaram para o segredo da Relação para que fossem ouvidos em confissão pelo frei José do Monte Carmelo antes de serem executados em praça pública.

Após relutar por sentir "uma repugnância em ir pessoalmente, tanto contra o q’ eu achava em mim para com outros em semelhantes ocazioens, q'e me obrigavao' a usar algumas pessoas", frei José chegou à noite no oratório da Relação para começar as confissões. O carmelita relata minuciosamente que assim como Manuel Faustino, com os outros condenados "teve o Demônio ocaziao" de lhes sugerirem o pensamento do suicídio, mas como Deus desejava salvá-los frei José passa então a descrever o arrependimento dos "condenados delinqüentes", ressaltando o milagre da Misericórdia divina no momento de suas conversões.

Manuel Faustino, segundo o carmelita descalço, pediu-lhe perdão por seus atos como forma de arrependimento, chegando, inclusive, a ser "Pregador para a conversao' de seus companheiros impenitentes". Frei José nos conta que foi a cena mais "terna ver este mancebo" chegando perto de João de Deus do Nascimento e lhe dizer "Joao' de Do convertete, e confeçate, olha q' ja não' temos remedio, apenas nos faltao'7 oras de vida, e não'queiras perderte; olha q'disgosto será $p^{a}$ tua mulher, teos filhos, e parentes, se morreres impeniten[te]". ${ }^{10}$

Lucas Dantas, segundo frei José, mereceu o empenho da Misericórdia divina para o "fazer feliz quanto elle trabalhou para ser eternamente desgraçado, porem como Deus jä previa ser elle, entre tantos culpados, um dos 4 desvalidos dos omens, e conduzido ao suplicio, quis muito antes defendelo de todas as desgraças, q' contra si mesmo intentava até o conduzir salvo à sua glória”. Não por acaso, o carmelita descalço novamente carrega na tinta o arrependimento de Lucas Dantas no segredo da Relação e, depois, em praça pública, afirmando que o mesmo, assim que subiu ao patíbulo, falou a "todo o povo; e pedio perdao' dos seus escandalos, [pediu] auxilio de Deos, e o amparo de sua May Santissima, levantou os olhos ao Céo e dali sentio baixar aquella mizericordia". ${ }^{11}$

Ao narrar o arrependimento dos condenados Manuel Faustino e Lucas Dantas como o milagre da Misericórdia divina, frei José afirma que sua intenção era demonstrar aos homens que com "estes dous pobres desvalidos, quis $D$ [eos] mostrar a todos as Luzes potentes q' as suas vistas estao' fixas nos pequeninos, $e$ q' favorece como Pai aos q' o mundo desprésa". Em seguida, o carmelita descalço procura demonstrar em seu relato "novas maravilhas nos outros dous Joao' de Deos, e Luiz Gonzaga", para que os homens soubessem que os milagres e prodígios " nao' estao' anexos aos tempos". ${ }^{12}$

Frei José nos conta que João de Deus e Luiz Gonzaga entraram no Oratório fingindo que perderam o juízo, parecendo uns loucos, de acordo com a junta de médicos que foi chamada para examiná-los. Segundo o carmelita descalço, como os réus insistiam em dar mostras de loucura e perda da razão, "tratamos fortemente de os converter, chegando a se juntar no Oratório até o número de vinte, e tantos Religiozos de todas as Religioens desta Cidade e Presbiteros Seculares; porem nada se pôde conseguir". ${ }^{13}$

Não obstante o número de religiosos chamados a "salvar" os réus, segundo frei José, a conversão dos réus só foi possível porque "a graça q' os havia converter, se guardava para aquelle instante no qual todos fossem testemunhas do seu poder, q' não' são' os omens, com seus discursos quem convertia aos outros omens, se 
não' Deos com a sua graça". De maneira distinta do relato acerca dos primeiros réus, no qual o carmelita descalço demonstra o arrependimento e a conversão dos mesmos na Relação e depois no espaço da praça pública, frei José justifica o fracasso no processo de conversão de João de Deus e Luiz Gonzaga no espaço privado do segredo da Relação conferindo uma dimensão política aos desígnios de Deus e, no limite, à religião, afirmando que "farao' ultimamente conduzidos impenitentes ao patíbulo fazendo se sensivel a toda a Cidade tal desgraça para q' depois fosse a todos os omens a mizericórdia mais notável'. ${ }^{14}$

Assim, na manhã quente de 8 de novembro de 1799, segundo o frei, as tropas de linha ocuparam desde cedo a Praça da Liberdade, amplo quadrilátero localizado no centro de Salvador. O povo curioso não parava de chegar. Estabeleceu-se um cordão de isolamento entre a tropa e o patíbulo público construído especialmente para a ocasião. Pelas onze horas, iniciou-se a procissão. À frente, banda de cornetas e tambores, seguida das irmandades revestidas das suas opas e capas, de cruz alçada e com seus respectivos vigários. Logo após, os condenados a degredo caminhavam de mãos atadas às costas, precedidos do porteiro do Conselho, com as insígnias do seu cargo, seguido dos quatro réus condenados à pena capital pelo crime de lesa-majestade de primeira cabeça, acompanhados de dois frades franciscanos, além de todos os escrivães, meirinhos e o porteiro do Tribunal da Relação da Bahia. Seguiam-nos empunhando a bandeira de Portugal o Senado da Câmara, os vereadores, os alcaides-mores e mirins, e o procurador do Conselho. Mais atrás, a irmandade da Misericórdia e o carrasco, ostentando as insígnias de seu ofício.

As gentes iam lotando as janelas das casas para ver a procissão dos condenados. $\mathrm{O}$ cortejo percorreu as ruas da Sé, desde o Terreiro de Jesus até o cimo da ladeira do Tira Preguiça, chegando em frente à Piedade. Após o ruflar dos tambores, o meirinho-mor leu pela última vez os pregões reais que anunciavam a morbidez com a qual os acusados seriam punidos por serem considerados pelas autoridades régias os cabeças da "projectada revolução" que instituiria um governo democrático no Brasil. Diante dos três regimentos pagos daquela praça, postos em armas para prevenir qualquer acidente que pudesse originar em favor dos réus, os condenados subiram ao cadafalso.

O primeiro a ser enforcado foi Luiz Gonzaga das Virgens e Veiga. Antes, segundo o carmelita descalço, o réu o chamou para um "ato de protestação", arrependendo-se de seus atos, especialmente por ter desrespeitado a Igreja. A "admiração que cauzou a todos o q' dice Gonzaga foi singular". ${ }^{15}$ Afirma o carmelita que Luiz Gonzaga disse para todos ouvirem "eu confeço, q'este Pai piedozo [...] derramou não só por elles, mas também por muitos o seu sangue para me salvar; neste espero o meu remédio [...]". Continuou sua confissão pública queixando-se do dano que lhe causaram as más companhias, aconselhando a todas as gentes a fugirem delas, e pediu perdão por não ter seguido os virtuosos conselhos que sua madrinha lhe dera. ${ }^{16}$ Terminou fazendo as mais "ternas súplicas a Deus para q' se dignasse salvalo (sic)". Após a confissão, foi enforcado, em meio à comoção das gentes diante de suas exclamaçôes.

Chorando muito após presenciar o enforcamento de Luiz Gonzaga das Virgens e Veiga, João de Deus do Nascimento pede que frei José se aproxime para "um fervoroso ato de contrição".${ }^{17}$ Segundo o carmelita descalço, minutos antes de ser enforcado, João de Deus despediu-se da vida dizendo ao "inumerável povo que se encontrava naquela praça" que

Sigao' a ley [do] verdadeiro Deos, a Religiao' Catolica he, a so e única verdadeira, e tudo o mais he engano; quando eu a seguia sem duvida alguma vivia e nao' (sic) bem ainda q'pobre, talvez independente, porem depois q'eu dei ouvidos a uns cadernos, a um Voltaire, a um Calvino, a um Rousseau, deixei o q'nao' devera e por isso vim parar a este lugar. Senhores quem quizer ser mau seja so para si, e nao' convoque os mais. $[\ldots]$ Liberdade e igualdade he isto apontando $\mathrm{p}^{\mathrm{a}}$. a forca. ${ }^{18}$

Ainda de acordo com o frei

[...] dizia João de Deus a todos q’ o ouviao' e sendo chegado o último momento de sua vida, e emplorando de Deus misericórdia, e pedindo socorro dos Sacerdotes; pedio também ao algoz q' lhe desse uma boa morte. Então' antes que caísse do patíbulo, agitandosse (sic) até morrer, e gritando por Jesus Maria, chaio ultimamente do patíbulo, acabando a ultima de suas palavras na vida dizendo: misericórdia, misericórdia... ${ }^{19}$ 
À execução dos outros dois réus seguiu-se o esquartejamento dos corpos. A cabeça de Lucas Dantas foi degolada, assim como as dos outros três, e depois espetada em um poste no Dique do Desterro. Os outros pedaços foram expostos no caminho do Largo de São Francisco, onde Lucas Dantas residiu. Em frente ao mesmo local, foi colocada a cabeça de Manuel Faustino dos Santos Lira, por ser ele frequentador assíduo daquela residência e por não ter endereço fixo. A cabeça de João de Deus foi exposta na rua Direita do Palácio, atual rua Chile; suas pernas, os braços e o tronco foram espalhados pelas ruas do Comércio, local de grande movimento da Cidade Baixa. No patíbulo ficaram espetadas as cabeças e as mãos de Luiz Gonzaga, por ter sido considerado pelas autoridades régias o responsável pelos pasquins que anunciaram à população a "projectada revolução".

No dia seguinte ao mórbido espetáculo, os corpos expostos ao calor davam sinais de rápida decomposição e atraíam uma revoada de urubus que enchiam a cidade de emanações pestilentas. No dia 11 de novembro de 1799, o ar da cidade era irrespirável; a podridão invadira todas as casas e a população temia por sua saúde. Diante do precário estado sanitário da cidade, algumas autoridades e irmãos da Misericórdia intervieram junto ao governador d. Fernando José de Portugal e Castro, solicitando a retirada dos corpos mortos e expostos a mando da justiça para o exemplo dos povos. O pedido foi deferido na madrugada do dia 15. Os despojos foram recolhidos pelas autoridades e enterrados em local até hoje desconhecido.

Como quase todos os condenados em seus momentos finais de vida clamaram perdão à Virgem Maria, o religioso cria que o seu relato perpetuasse na memória do povo o prodígio dos desvalidos condenados e a misericórdia divina que, em terra, os homens não foram capazes de lhes conceder. Entretanto, no final da narrativa, frei José questiona a pena imputada aos quatro réus, mas o faz afirmando que o milagre da misericórdia divina só foi possível porque Deus, que tudo vê, sabia que os quatro homens enforcados em praça pública não foram os únicos que cometeram o delito régio, "provando se lhes como diz a Sentença de terem sido cabeças de uma sublevação q' nesta mesma Cidade se intentara". ${ }^{20}$ Assim, "depois q' forão justiçados os ditos padecentes; aos quaes assisti dentro do Oratório de dia, e de noite...", o carmelita descalço afirma finalmente:

ao segundo q' eu tenho como de Fé, q'sendo tantos os culpados no mesmo delito, e q' se estes 4 por desvalidos pagarao' com pena ultima Deus q' olha os pequeninos [réus], e abraça estes q' olham do desprezo; permitio q' a mizericordia se fizesse. ${ }^{21}$

Demonstrando que a luz da misericórdia divina venceu o mal das trevas das tentaçōes do demônio, exteriorizadas na tentativa de suicídio dos réus, o relato laudatório do frei José do Monte Carmelo parece indicar duas questões caras à conjuntura do final do século XVIII, em Salvador. A primeira delas é a dimensão política dos desígnios de Deus. Ainda que no relato haja a descrição do arrependimento dos réus no segredo da Relação, frei José, como se viu, carrega na tinta ao demonstrar que o milagre da misericórdia divina efetivamente ocorreu em praça pública, na presença de um "povo inumerável". E o objetivo de frei José parece muito claro ao querer perpetuar na memória do povo "o prodígio dos desvalidos réus".

O religioso, abstraindo a "repugnância" inicial que sentiu ao ser chamado a ouvir a confissão dos "réus delinqüentes", argutamente explicita sua crítica ao processo de secularização das ideias, no final do século XVIII, através da vitória de Deus no verdadeiro embate com o demônio: as luzes divinas exteriorizadas no milagre da misericórdia vencendo as luzes da razão iluminista. Esse embate aparece na narrativa do carmelita descalço quando os acusados são convertidos de "réus delinqüentes" em "pequeninos" após o arrependimento por projetarem uma revolta e rejeitarem os preceitos da religião católica, quando deram "ouvidos a um Voltaire, a um Calvino, a um Rousseau".

Neste particular, frei José parece sugerir que a desobediência dos réus ao tentarem uma revolta ocorreu em função de uma espécie de "inocência moral” subjugada pela escuridão das paixões humanas, das luzes da razão, que só o milagre da misericórdia divina poderia frear. Não parece ser por outra razão que Manuel Faustino, o primeiro réu a ser ouvido em confissão, deixa de ser um "réu delinquente" para ser considerado um "pequenino pregador para a conversão" dos outros réus, fazendo com que o carmelita 
descalço também convertesse, quase como um outro milagre divino, a "repugnância" inicial que sentiu pelos réus em outro sentimento mais nobre, "pelo sentimento da sua morte [Manuel Faustino], pois lhe tinha adquirido grande amor" ${ }^{22}$

Ainda que não haja referência, no relato do carmelita descalço parece tomar vulto a ideia da misericórdia divina como o freio das paixões humanas em um contexto em que a verdade moral passa a ser balizada e tensionada pelos ideais da Revolução Francesa, Revolução de São Domingo e o liberalismo em curso. ${ }^{23}$ Frei José do Monte Carmelo parece associar a revolta à paixão não como o desejo que brota do sujeito, mas a paixão como algo que afeta, que se impõe aos homens, que os cega, pondo-os fora de si e de sua natureza primitiva, que os torna loucos quando deixam de dar ouvidos a religião católica. Neste sentido, os momentos finais de João de Deus do Nascimento e de Luiz Gonzaga, que, como se viu, aparecem na narrativa como uns loucos desvairados, é significativo da imperativa necessidade da fé se sobrepor à razão, de tal sorte que frei José afirma que, para tanto, foi preciso o esforço de vinte religiosos de todas as religiōes na tentativa de convertê-los no segredo da Relação. Milagre da misericórdia que só ocorreu em praça pública porque, segundo frei José, Deus quis mostrar a força das “luzes divina" a "um povo inumerável".

Não à toa, a crítica elaborada pelo frei às ideias de Voltaire, Calvino e Rousseau aparece teatralizada a partir do resgate do drama do enforcamento e esquartejamento dos quatro "pequeninos", em especial dos réus que simularam loucura e perda da razão. Nesse caso, o perigo do desvio da natureza humana, a paixão, as luzes da razão, como a possibilidade de corromper o homem e o tecido social, parece ser uma das faces do relato laudatório do frei que, ao se deixar arrebatar pelo conteúdo normativo da sociedade baiana do final do século XVIII, converte o milagre da misericórdia divina, após o arrependimento dos condenados, como parte da dimensão política da punição exemplar.

A dimensão política conferida ao milagre da misericórdia divina é um dos desdobramentos da lógica da punição exemplar e a segunda questão relevante da narrativa de frei José do Monte Carmelo. Isso porque, além de o arrependimento dos réus em praça pública ter significado a conversão dos mesmos, ele também significou uma confissão pública. Cabe lembrar que na narrativa de frei José o arrependimento dos condenados ocorreu em momentos de suplício dos mesmos. Significativas, neste sentido, foram as palavras finais de João de Deus do Nascimento que disse "entre muitas lágrimas", no momento que seria enforcado, "sigao' a ley de Deos, a Religiao' Catolica [...] quando eu a seguia sem duvida alguma vivia bem ainda q'pobre [...] Liberdades e igualdades he isto", apontando para a forca e sendo enforcado em seguida.

Segundo Foucault, as puniçóes exemplares no Absolutismo tinham em comum o fato de comportarem algum tipo de sofrimento físico e, portanto, tinham por alvo o corpo. Mesmo nas formas de punições mais recorrentes, como o banimento, pode-se encontrar alguma dimensão de "suplício", seja pela exposição, pela multa, pelo açoite ou marcação a ferro. Longe de ser um procedimento selvagem, o autor nos chama atenção para o fato de que o suplício é uma forma de sofrimento calculado, no qual o poder político procura estabelecer publicamente relações causais entre o crime e a punição, de acordo com os usos políticos que se pode ter nesse procedimento. Portanto, como um dos últimos espetáculos punitivos do absolutismo português no Brasil, o suplício dos réus da Conjuração Baiana de 1798 não corresponde apenas ao castigo corporal, mas também e, sobretudo, a um ritual organizado de maneira a reforçar o poder da monarquia portuguesa no Brasil. ${ }^{24}$

O ritual do suplício expressa, portanto, a suntuosidade da soberania, a força do monarca em seu exercício de direito. A morte dos réus no patíbulo público da cidade de Salvador, com efeito, foi um espetáculo que objetivou reafirmar a clivagem entre as forças do soberano e do súdito, uma vez que o suplício dos réus narrados pelo frei José pode ser considerado como um modo bastante eficaz de fazer funcionar, até um extremo, a dessimetria entre o súdito que ousou violar a lei e o poder absolutista que faz valer sua força. Ainda segundo Foucault, se a reparação do dano privado ocasionado pelo delito deve ser bem proporcionada e a sentença deve ser justa, a execução da pena pública é feita não para dar o espetáculo da medida, mas do desequilíbrio e do excesso; devendo haver nessa liturgia da punição exemplar 
para crime de lesa-majestade uma afirmação enfática do poder e de sua superioridade intrínseca. E esta superioridade não é simplesmente a do direito, mas da força física do soberano. ${ }^{25}$

A punição na soberania é menos uma vingança - apenas um sentimento pessoal do monarca -, do que uma ação política efetiva, uma vez que o delito é uma ameaça à ordem e o espetáculo da punição exemplar é feito para ser o de partida para o restabelecimento dessa mesma ordem ameaçada. Só que a punição exemplar, como se viu no relato de frei José, não foi encerrada com o enforcamento dos réus. Por seu caráter de espetáculo, os suplícios se prolongaram ainda depois dos enforcamentos, com o esquartejamento dos corpos e a exposição pública das partes em locais nos quais os réus habitavam e circulavam com certa frequencia. Ocorre que o prolongamento dos suplícios e do espetáculo punitivo, em alguns casos, acaba invertendo os papéis, fazendo que o condenado às vezes seja um objeto de piedade e de admiração.

Talvez essa seja uma das razões para a conversão dos sentimentos de frei José do Monte Carmelo em relaçōes aos réus, transubstanciando-os de delinquentes em pequeninos, e para a necessidade de perpetuar na memória do povo os momentos finais daqueles homens logo após o enforcamento seguido do esquartejamento das partes, ressaltando o arrependimento dos mesmos e a conversão como exteriorização do milagre da misericórdia divina. Seja como for, ainda permanecerá aberta uma última questão em relação à narrativa de frei José e as informações que se apreende dos autos das devassas da Conjuração Baiana de $1798 .{ }^{26}$

Como se viu, o prior dos carmelitas descalços foi escolhido pelos "anônimos republicanos" como chefe do que viria a ser a Igreja na "República Bahinense", ${ }^{27}$ ao mesmo tempo em que eles foram os padres chamados a acompanhar os momentos finais dos réus. Sendo frei José do Monte Carmelo o prior dos carmelitas descalços, caberia considerar, nesse caso, a argúcia das autoridades locais quando o convocaram para acompanhar os momentos finais de vida dos réus. A esse respeito, cumpre destacar que Affonso Ruy e Florisvaldo Mattos citam parte de um documento cujo conteúdo sugere que o carmelita descalço não só sabia dos acontecimentos em curso como mantinha relações com o grupo de notáveis - proprietários dos escravos indiciados nas devassas da Conjuração Baiana de 1798. Especialmente o Secretário de Estado e Governo do Brasil, José Pires de Carvalho e Albuquerque, que além de entregar quatro de seus escravos aos desembargadores do Tribunal da Relação da Bahia, foi o responsável pelo órgão em que as Devassas do movimento foram recolhidas. ${ }^{28}$

O documento citado pelos autores é uma carta escrita por José da Silva Lisboa a Cipriano Barata, afirmando que "[...] Já o José Pires Albuquerque lhe deve ter comunicado a resolução dos nossos amigos do Recôncavo. Tenha cuidado com o frei José e o frei Francisco na disputa que mantém quanto ao querer cada qual ser o chefe da Igreja". ${ }^{29}$ Cumpre destacar que no final do seu relato, frei José, talvez arrependido por saber dos acontecimentos em curso no ano de 1798, fez questão de afirmar que os réus não foram os únicos culpados no "delito de sublevação".

A esse respeito, tudo leva a crer que o relato de Frei José do Monte Carmelo caminha para a superação de uma possível culpa em relação aos condenados, mas, também, caminha na direção de uma crítica conservadora em relação ao que a narrativa sugere ter havido no encaminhamento das investigações: a atuação duvidosa das autoridades locais que condenaram apenas quatro homens desvalidos diante de tantos culpados. Corrobora para essa hipótese a informação de um anônimo provavelmente escrita logo após as primeiras prisões ordenadas pelo governador, insinuando que o Secretário de Estado, José Pires de Carvalho e Albuquerque entregou os seus escravos à justiça, na expectativa de não ser acusado de participação no levante. ${ }^{30}$

Seja como for, a maneira teatralizada pela qual o carmelita descalço elaborou a sua narrativa, chamando de certa forma a atenção para a iniquidade do poder local em relação ao enforcamento dos quatro réus na Praça da Piedade, resgatando o drama desses homens livres, pobres e pardos, arrependidos por terem ouvido as ideias de liberdade e igualdade, é paradigmático da posição do carmelita descalço em relação às forças diametralmente opostas no final do século XVIII: razão/revelação; liberdade/despotismo; natureza/civilização; moral/política; luzes/trevas. A curiosa maneira de frei José do Monte Carmelo encarar o problema acerca da punição exemplar na Conjuração Baiana de 1798, faz parte de uma perspectiva na qual o religioso e o político passam a ser partes de um todo e, portanto, passível tanto de apreciação co- 
mo de crítica, ainda que muito conservadora, como se teve oportunidade de demonstrar. Parece inegável que o que está subjacente à crítica conservadora do carmelita descalço é uma questão ainda não resolvida: os quatro homens livres, pobres e pardos terem sido os únicos culpados pelo "delito de sublevação" quando tudo leva a crer que a composição social da Conjuração Baiana de 1798 é um pouco mais ampla do que a definida pelos Desembargadores do Tribunal da Relação da Bahia, em 1799.

\section{Notas}

${ }^{1}$ A melhor transcrição dos boletins manuscritos preservados e das cartas citadas está em Kátia M. de Queirós Mattoso. Presença francesa no Movimento Democrático Baiano de 1798. Salvador: Itapuã, 1969. Para uma visão de conjunto da historiografia da Conjuração Baiana de 1798, ler: Kátia M. Q. Mattoso. Bahia 1798: os panfletos revolucionários. Proposta de uma nova leitura. In: Osvaldo Coggiola (org.). A Revolução Francesa e seu impacto na América Latina. São Paulo / Brasília, Nova Stella / EDUSP / CNPq, 1990, pp. 341-56; István Jancsó. Na Bahia, contra o Império: história do ensaio de sedição de 1798. São Paulo / Salvador: HUCITEC / EDUFBA, 1996; Luís Henrique Dias Tavares. História da sedição intentada na Bahia em 1798 (A Conspiração dos Alfaiates). São Paulo / Brasília, Pioneira / INL, 1975.

${ }^{2}$ Auto do exame, e Combinação das Letras dos pasquins e mais papéis sediciozos, que apparecerão nas esquinas, ruas, e Igreja desta Cidade que se achão incorporados na Devassa... In: Autos da Devassa da Conspiração dos Alfaiates. Salvador: Arquivo Público do Estado da Bahia, 1998, 2 Volumes. Doravante: ADCA, vol. 1, p. 89.

${ }^{3}$ ADCA, vol. 1, pp. 39-40.

${ }^{4}$ Idem.

${ }^{5}$ Ibidem.

${ }^{6}$ Outra relação feita pelo P. Fr. Joze D’Monte Carmelo, religiozo carmelita descalço. Instituto Histórico e Geográfico Brasileiro, Notícia da Bahia, tomo IV, Lata 402, manuscrito 69. Arquivo Histórico Ultramarino, inventário Castro e Almeida, Bahia, documentos avulsos, caixas: 41 a 82. O documento "Outra relação...” está integralmente transcrito na obra de Luís Henrique Dias Tavares. História da Sedição intentada na Bahia em 1798 (A Conspiração dos Alfaiates). São Paulo/Brasília: Pioneira/INL, 1975, pp. 123-137, passim.

${ }^{7}$ A ordem dos Carmelitas surgiu no final do século XI, na região de Monte Carmelo, na Palestina. A partir do século XVI, já no Ocidente, especificamente na Espanha, os Carmelitas passaram por um movimento de renovação com Santa Tereza D’Ávila e São João da Cruz. A ordem foi dividida em Carmelitas Calçados, que seguiam a ordem antiga, e os Carmelitas Descalços seguidores do movimento renovador. A ordem chegou ao Brasil em 1580 e estabeleceu-se em Pernambuco, onde fundou o Convento do Carmo de Olinda, em 1583. Estabeleceram-se na cidade de Salvador, em 1586, onde fundaram seu segundo convento. A esse respeito ler: Eduardo Hoornaert. História da Igreja no Brasil. Petrópolis: Vozes, 4ª edição, 1992; Waldemar Mattos. Os Carmelitas Descalços na Bahia. Salvador: Manú, 1964. Luís dos Santos Vilhena, entretanto, afirma que os Carmelitas Descalços fundaram seu mosteiro na Bahia em 1665. Cf. Vilhena, op. cit., vol. 2, p. 446.

${ }^{8}$ Tavares, op. cit., p. 124.

${ }_{9}$ Idem, p. 125.

${ }^{10}$ Idem, p. 127.

${ }^{11}$ Idem, p. 130.

${ }^{12}$ Ibidem.

${ }^{13}$ Idem, p. 131.

${ }^{14}$ Ibidem.

15 Idem, p. 134.

${ }^{16} \mathrm{O}$ nome da madrinha de Luiz Gonzaga das Virgens e Veiga permanece desconhecido. Sabe-se, no entanto, que ela era esposa de Pedro Nolasco de Sã Marinho de Azevedo, senhor do engenho São Cosme Damião, à época termo da vila de Santo Amaro da Purificação. No depoimento realizado em 28 de agosto de 1798, Pedro Nolasco confirmou ser de Luiz Gonzaga as letras dos pasquins sediciosas e afirmou ao desembargador Avellar e Barbedo que "dava de comer [a Luiz Gonzaga] por caridade, por ter sido afilhado da defunta sua mulher”. Cf. Assentadas, pp. 43-44, vol. I. In: Autos da devassa da Conspiração dos Alfaiates. Salvador: Arquivo Público do Estado da Bahia, 1998. Doravante: ADCA. Sobre Luiz Gonzaga das Virgens, ler Luís Henrique Dias Tavares. O soldado Luís Gonzaga das Virgens. In: Da sedição de 1798 à revolta de 1824 na Bahia. Editora da Unesp/ EDUFBA: São Paulo/Salvador, 2003, pp. 55-84.

${ }^{17}$ Idem, p. 135.

${ }^{18}$ Ibidem. Grifo meu.

${ }^{19}$ Outra Relação..., p. 137. 
${ }^{20}$ Idem, p. 136. Grifo meu.

${ }^{21}$ Ibidem, p. 137.

${ }^{22}$ Idem, p. 127.

${ }^{23}$ A respeito de a inocência moral ser projetada no presente pelos oprimidos como forma de contestação, ler Reinhart Koselleck. Crítica e crise. Rio de Janeiro: EDUERJ/Contraponto, 1999, p. 19.

${ }^{24}$ Cf. Michel Foucault. Vigiar e punir. Petrópolis: Vozes, 1987, 22a edição.

${ }^{25}$ Idem, p. 46.

${ }^{26}$ ADCA, vol. 1, pp. 39-40.

${ }^{27}$ Cumpre destacar que o local marcado para o encontro entre os partícipes da revolta, na noite de 25 de agosto de 1798 , ficava nas cercanias do convento de Santa Clara do Desterro, das clarissas enclausuradas de véu preto. Trata-se de um importante grupo de mulheres provenientes das mais ricas famílias baianas da época, em razão de suas atividades creditícias e dos engenhos hipotecados ao convento. Chamo a atenção para o fato de que o Secretário de Estado José Pires de Carvalho e Albuquerque tinha quatro irmãs: Teresa Mariana do Livramento (Abadessa de 1805-1808), Mariana Francisca do Coração de Jesus (Abadessa de 1808-18011), Antonia de Jesus Maria e Teresa Josefa do Paraíso, que foi Abadessa reeleita durante os períodos de 1793-1797; 1797-1802. Cf. Anna Amélia Vieira do Nascimento. Patriarcado e religião: as enclausuradas clarissas do Convento do Desterro da Bahia (1677-1890). Salvador: Conselho de Cultura, 1994, pp. 483-484.

${ }^{28}$ A personalidade mais proeminente do grupo de notáveis foi, sem dúvida, o proprietário de importantes engenhos José Pires de Carvalho e Albuquerque, e não por acaso seu escravo foi o único a ter direito do auto de justificação. Segundo "attestação" do então Governador da Bahia, d. Rodrigo José de Menezes, de 03 de janeiro de 1788, José Pires de Carvalho e Albuquerque "servia nos empregos" de Secretário de Estado e Governo do Brasil, cargo que era proprietário por herança; de Intendente da Marinha e Armazéns Reais; Vedor Geral do Exército; Provedor e Ouvidor da Alfândega da Bahia e Deputado da Junta da Real Fazenda - órgão em que os Autos das Devassas foram recolhidos por ordem de d. Fernando José de Portugal e Castro. O nome do Secretário é citado nas duas devassas, por ocasião da "pronta entrega de seus escravos", comprovada no depoimento do Sargento-mor, Fortunato da Veiga São Paio, em 4 de outrubro de 1798, quando afirmou ao desembargador Costa Pinto "que não sabia, nem prezumia porquanto o Secretário deste EstadoJoze Pires de Carvalho e Albuquerque, na manhã de hoje, foi a caza de sua Cunhada Dona Maria Francisca da Conceição e Aragão, onde residia elle declarante, e o mandou juntamente com o pardo Joze, escravo da mesma Dona Maria, para estas cadeas, dizendo era [ser] para huma averiguação". In: ADCA, vol. II, p. 758. A esse respeito, ler: Luís Henrique Dias Tavares, op. cit.; Patrícia Valim. Da Sedição dos mulatos à Conjuração Baiana de 1798: a construção de uma memória histórica. Dissertação de mestrado, FFLCH/USP, 2007.

${ }^{29}$ Cf.Affonso Ruy. A primeira revolução social brasileira. Salvador: Ed. Beneditina, 1951, p. 54; Florisvaldo Mattos. A comunicação social da Revolução dos Alfaiates. Salvador: Assembléia Legislativa do Estado da Bahia, 1998, p. 135. Chamamos atenção para o fato de que até o momento não encontramos o documento original para confirmar a informação dos autores.

${ }^{30}$ Cf. Descrição da Bahia: relação de francezia formada pelos homens pardos da cidade do Salvador, Tomo IV, pp. 294-301. Arquivo do IHGB, DL. 399.2.

\section{Referências bibliográficas}

AMARAL, Braz do. A Conspiração Republicana de 1798. Rio de Janeiro: Imprensa Nacional, 1927.

BARROS, Francisco Borges de. Os Confederados do Partido da Liberdade. Salvador: Imprensa Oficial do Estado, 1922.

. Primórdios das Sociedades Secretas da Bahia. Salvador: Imprensa Oficial do Estado, 1929.

FOUCAULT, Michel. Vigiar e punir. Petrópolis: Vozes, 1987, 22a edição.

JANCSÓ, István. Na Bahia contra o Império: história do ensaio de sedição na Bahia de 1798. São Paulo: Hucitec, 1996.

A Sedução da liberdade: cotidiano e contestação politica no final do século XVIII. In: SOUZA, L. de M. e (Org.). História da vida privada no Brasil, cotidiano e vida privada na América Portuguesa, vol. 1. São Paulo: Companhia das Letras, 1999.

. Bahia 1798: a hipótese do auxílio francês ou a cor dos gatos. In: FURTADO, J. F. (Org.). Diálogos Oceânicos: Minas Gerais e as novas abordagens para uma história do Império Ultramarino Português. Belo Horizonte: Ed. UFMG, 2001.

KOSELLECK, Reinhart. Critica e crise. Rio de Janeiro: Eduerj/Contraponto, 1999.

MATTOS, Florisvaldo. A comunicação social da Revolução dos Alfaiates. Salvador: Assembléia Legislativa do Estado da Bahia, 1998. 
MATTOSO, Kátia M. de Queirós. Da Revolução dos Alfaiates à riqueza dos baianos no século XIX. Salvador: Corrupio, 2004.

. Babia, século XIX: uma província no Império. Rio de Janeiro: Nova Fronteira, 1992.

. Presença francesa no Movimento Democrático Baiano de 1798. Salvador: Itapuã, 1969.

NASCIMENTO, Anna Amélia Vieira do. Patriarcado e Religião: as enclausuradas clarissas do Convento do Desterro da Bahia (1677-1890). Salvador: Conselho de Cultura, 1994.

NOVAIS, Fernando Antonio. Portugal e Brasil na crise do Antigo Sistema Colonial (1777-1808). São Paulo: Hucitec, 1979 (7 $7^{\text {a }}$ dição, 2001).

PRADO JÚNIOR. Caio. Evolução política do Brasil e outros estudos. São Paulo: Brasiliense, 1975.

RUY, Affonso. A primeira revolução social brasileira. Salvador: Ed. Beneditina, 1951.

SILVA, Inácio Accioli de Cerqueira e. Memórias Históricas e Políticas da Bahia, anotadas por Braz do Amaral, 6 vols. Bahia: Imprensa Oficial, 1919-1940.

. Memórias Históricas e Políticas da Provincia da Bahia. Bahia: Typ. Do Correio Mercantil, de Précourt, 1835, Tomo I.

TAVARES, Luís Henrique Dias. História da Bahia. São Paulo: Editora da Unesp, 2001.

História da Sedição intentada na Bahia em 1798 (A Conspiração dos Alfaiates). São Paulo/Brasília: Pioneira/INL, 1975.

. Da sedição de 1798 à Revolta de 1824 na Bahia. São Paulo/Bahia: Editora da Unesp/EDFBA, 2003.

VALIM, Patrícia. O preço da Liberdade. Revista de História da Biblioteca Nacional, Ano 1, no 10, maio-julho/2006, pp. 68-71.

. "O tempo em que todos seremos iguais". Revista História Viva, Ano V, no 49, novembro, 2007, pp. 88-92.

Da Sedição dos mulatos à Conjuração Baiana de 1798: a construção de uma memória histórica. Dissertação de Mestrado, DH/FFLCH/USP. São Paulo, 2007.

VARNHAGEN, Francisco Adolfo. História geral do Brasil antes de sua separação e independência de Portugal. Belo Horizonte/São Paulo: Itatiaia/Edusp, 10ª edição integral, 1981.

VILHENA, Luís dos Santos. Recopilação de notícias soteropolitanas e brasilicas. Salvador: Itapuã, 1969.

\section{RESUMO}

Condenados por conspirarem contra a monarquia portuguesa, na ensolarada manhã do dia 8 de novembro de 1799 , quatro homens livres, pobres e pardos foram enforcados na Praça da Piedade, na cidade de Salvador. Graças aos relatos de um carmelita descalço, frei José do Monte Carmelo, sabe-se atualmente como foram os momentos finais dos quatro réus condenados à pena capital pelo crime de lesa-majestade. Para além de relatar o suplício daqueles quatro homens, o relato do carmelita suscita duas questôes importantes acerca do conhecimento que se tem atualmente da Conjuração Baiana de 1798. A primeira é a posição de um religioso cristão em relação às forças diametralmente opostas no final do século XVIII: razão / revelação; liberdade / despotismo; natureza / civilização; moral / política; luzes / trevas. Depois, ao resgatar o drama do enforcamento dos quatro réus, arrependidos em praça pública, por terem ouvido as ideias de liberdade e igualdade, o carmelita descalço afirma em sua narrativa que não foram eles os únicos culpados no "delito de sublevação", sugerindo ter havido iniquidade do poder local em relação à circunscrição social do evento. É o que se apresenta neste artigo.

Palavras-chave: conjuração, punição, carmelita, Bahia, século XVIII.

\section{ABSTRACT}

November 8, 1799, four poor free colored men were hanged at Piedade square, Salvador. They had been convicted of conspiracy against the Portuguese Crown. Thanks to a report by a Carmelite friar, José do Monte Carmelo, who heard the confessions of the four convicts, we know about the last moments of those four men. His report deals with two different issues regarding the 1798 Conspiracy in Bahia. One is the position of a Christian regarding opposing forces: re- 
ason/revelation, freedom/despotism, naturelcivilization, morallpolitics, and enlightenment/darkness. The other one is that, in addition to the drama presented by the hanging of four men, who publicly repented for listening to the ideas of freedom and equality, the Carmelite friar also reported that those men were not the only ones who were guilty of the said events afore done. He further suggests the local authorities had not been fair, implying that there could have been people from higher social positions involved in the conspiracy. This is the subject of this paper. Keywords: conspiracy, punishment, Carmelite friar, Bahia, XVIII century. 